\title{
Slug overexpression is associated with poor prognosis in thymoma patients
}

\author{
TIANQIANG ZHANG，XU CHEN，XIUMEI CHU，YI SHEN，WENJIE JIAO，YUCHENG WEI, \\ TONG QIU, GUANZHONG YAN, XIAOFEI WANG and LINHAO XU
}

Department of Thoracic Surgery, The Affiliated Hospital, Qingdao University, Qingdao, Shandong 266003, P.R. China

Received November 4, 2014; Accepted May 22, 2015

DOI: $10.3892 / 01.2015 .3851$

\begin{abstract}
Slug, a member of the Snail family of transcriptional factors, is a newly identified suppressive transcriptional factor of E-cadherin. The present study investigated the expression pattern of Slug in thymomas to evaluate its clinical significance. Immunohistochemistry was used to investigate the expression pattern of the Slug protein in archived tissue sections from 100 thymoma and 60 histologically normal thymus tissue samples. The associations between Slug expression and clinicopathological factors, such as prognosis, were analyzed. Positive expression of Slug was detected in a greater proportion of thymoma samples [51/100 (51\%) patients, $\mathrm{P}<0.001]$ compared with normal thymus tissues [9/60 (15\%) cases]. Of the 100 patients with thymoma, 42 (42\%) displayed high levels of Slug expression (high-level group) and 58 (58\%) displayed low levels of Slug expression (low-level group). The 10-year survival rate was improved for patients in the low-level group when compared with those in the high-level group $(\mathrm{P}=0.002)$. A multivariate analysis using the Cox proportional hazards regression model demonstrated that Slug overexpression was not an independent prognostic factor. In conclusion, the present study demonstrated that Slug overexpression was associated with poor prognosis in patients with thymoma. Therefore, Slug may be a potential diagnostic biomarker and a predictor of poor prognosis in thymoma patients.
\end{abstract}

\section{Introduction}

Thymoma is an epithelial tumor of the thymus that is characterized by indolent growth with local invasiveness and is the most common type of tumor in the anterior portion of the mediastinum (1). The overall incidence of thymoma is rare, with $\sim 0.15$ cases per 100,000 cases/year $(2,3)$. Thymoma had

Correspondence to: Mr. Linhao Xu, Department of Thoracic Surgery, The Affiliated Hospital, Qingdao University, 16 Jiangsu Road, Qingdao, Shandong 266003, P.R. China

E-mail:wenshuai16@163.com

Key words: Slug, thymoma, prognosis, thymus previously been regarded as a benign disease, but more recent evidence indicated that it is a potentially malignant tumor requiring prolonged follow-up (4). However, biomarkers for thymoma diagnosis and prognosis have not yet been established.

Slug is a member of the Snail family of zinc-finger transcription factors and was first identified in the neural crest and developing mesoderm of chicken embryos (5). Slug induces the downregulation of E-cadherin, an adhesion molecule, leading to the breakdown of cell-cell adhesions and the acquisition of invasive growth properties in cancer cells (6). These changes facilitate an increase in spindle morphology and cellular invasion (7-9). Previous studies have demonstrated that Slug expression is associated with poor prognosis in colorectal carcinoma, esophageal cancer and breast carcinoma (10-13); however, the clinical relevance of Slug expression in thymoma remains unknown.

The aims of the present study were to examine Slug expression in thymoma and to determine whether the degree of Slug expression correlates with prognosis.

\section{Patients and methods}

Patients and specimens. Ethical approval for the present study was obtained from the medical ethics committee of the Affiliated Hospital of Qingdao University (Qingdao, China), and the study was performed in accordance with the institutional guidelines. Written informed consent was obtained from each patient prior to tissue acquisition.

Tissue specimens were obtained from 100 patients with thymoma who underwent thymectomy between January 1997 and December 2003 at the Affiliated Hospital of Qingdao University. Thymomas were classified according to the World Health Organization (WHO) criteria (14), and clinical stages are based on the Masaoka staging system (15). In addition, normal thymus tissues were obtained from 60 patients with mediastinal cysts who underwent cystectomy at the same institution between January 1997 and December 2003, and were set as the control group (Tables I and II). The normal tissue specimens were obtained from adjacent thymus tissues based on histological evidence of the surgically resected mediastinal cyst. Follow-up for all patients following discharge included an X-ray examination or computed tomography scan every 3-6 months. Postoperative follow-up data were 
Table I. Clinical characteristics of thymoma patients and controls (patients with mediastinal cysts).

\begin{tabular}{lccc}
\hline Characteristic & $\begin{array}{c}\text { Thymoma } \\
\text { patients }(\mathrm{n}=100)\end{array}$ & $\begin{array}{c}\text { Controls } \\
(\mathrm{n}=60)\end{array}$ & P-value \\
\hline $\begin{array}{l}\text { Mean age, years } \\
( \pm \mathrm{SD})\end{array}$ & $53.42 \pm 12.18$ & $48.93 \pm 10.17$ & $0.078^{\mathrm{a}}$ \\
$\begin{array}{l}\text { Gender, } \mathrm{n} \\
\text { Male }\end{array}$ & 54 & 33 & $0.902^{\mathrm{b}}$ \\
Female & 46 & 27 & \\
\hline
\end{tabular}

P-values calculated using the ${ }^{a}$ Students t-test or ${ }^{\mathrm{b}} \chi^{2}$ test. b SD, standard deviation.

obtained from all patients, and the median follow-up period was 99.7 months (range, 3-120 months).

Immunohistochemical staining and evaluation. The primary specimens were fixed in $10 \%$ formaldehyde and routinely embedded in paraffin. Next, 4- $\mu \mathrm{m}$ sections were prepared and immunohistochemical staining was performed using the streptavidin-biotin peroxidase method, as described previously (16). Briefly, following deparaffinization and hydration, the sections were washed in phosphate-buffered saline (PBS; 3 times, for 3 min each time), and the washed sections were treated with $3 \%$ hydrogen peroxide in the dark for $15 \mathrm{~min}$. The sections were washed initially in distilled water and then in PBS [3 times, for $5 \mathrm{~min}$ each time $(3 \times 5 \mathrm{~min})$ ]. Antigen retrieval was performed in Tris-ethylenediaminetetraacetic acid (EDTA; $10 \mathrm{mM}$ Tris, $1 \mathrm{mM}$ EDTA, $\mathrm{pH} 8.0$ ) at $120^{\circ} \mathrm{C}$ for $2 \mathrm{~min}$, and the sections were preincubated in PBS ( $3 \times 5 \mathrm{~min})$. Next, the sections were incubated with a rabbit anti-human Slug polyclonal antibody (dilution, 1:100; Slug H-140; catalog no. sc-15391; Santa Cruz Biotechnology, Inc., Santa Cruz, CA, USA) overnight at $4^{\circ} \mathrm{C}$. After washing in PBS ( $\left.3 \times 5 \mathrm{~min}\right)$, the sections were incubated with the secondary antibody (dilution, 1:1,000; Polink-2 HRP; catalog no. d22-110; Golden Bridge International, Inc., Bothell, WA, USA) at room temperature for $30 \mathrm{~min}$. The sections were washed again in PBS ( $3 \times 5 \mathrm{~min})$, treated with 3,3'-diaminobenzidine working solution at room temperature for $10 \mathrm{~min}$ and then washed in distilled water.

Two pathologists performed independent immunohistochemical evaluation using the following criteria: Positive Slug expression was defined as a detectable immunoreaction in either the nucleus or cytoplasm. The staining intensity was graded between 0 and 3 ( 0 , negative; 1 , weak; 2 , moderate; 3 , strong), and the extent of staining was graded between 0 and 4 (0, no staining; 1, 1-25\%; 2, 26-50\%; 3 , $51-75 \% ; 4,76-100 \%)$. The overall staining was scored by multiplying the intensity of the staining (when viewed at x200 magnification; BX41 Olympus microscope; Olympus Corporation, Tokyo, Japan) by the extent of staining (when viewed at $\mathrm{x} 40$ magnification). Therefore, the staining scores ranged between 0 and 12 .

Statistical analysis. The $\chi^{2}$ test and t-test were used to calculate differences between the thymoma group and the control
Table II. Slug expression in relation to clinicopathological findings.

\begin{tabular}{|c|c|c|c|c|}
\hline \multirow[b]{2}{*}{ Variables } & \multirow[b]{2}{*}{$\begin{array}{c}\text { Total, } \\
\mathrm{n}\end{array}$} & \multicolumn{2}{|c|}{ Slug } & \multirow[b]{2}{*}{ P-value } \\
\hline & & $\begin{array}{l}\text { High-level } \\
\text { group, n }\end{array}$ & $\begin{array}{l}\text { Low-level } \\
\text { group, n }\end{array}$ & \\
\hline $\begin{array}{l}\text { Mean age, } \\
\text { years }( \pm S D)\end{array}$ & $\begin{array}{c}53.42 \\
\pm 12.18\end{array}$ & $\begin{array}{c}50.74 \\
\pm 12.76\end{array}$ & $\begin{array}{c}55.53 \\
\pm 12.97\end{array}$ & 0.069 \\
\hline Gender & & & & 0.592 \\
\hline Male & 54 & 24 & 30 & \\
\hline Female & 46 & 18 & 28 & \\
\hline Stage & & & & $<0.001$ \\
\hline I & 48 & 9 & 39 & \\
\hline II & 19 & 9 & 10 & \\
\hline III & 26 & 19 & 7 & \\
\hline IV & 7 & 5 & 2 & \\
\hline Classification & & & & 0.013 \\
\hline $\mathrm{A}, \mathrm{AB}, \mathrm{B} 1$ & 55 & 17 & 38 & \\
\hline $\mathrm{B} 2, \mathrm{~B} 3, \mathrm{C}$ & 45 & 25 & 20 & \\
\hline MG & & & & 0.478 \\
\hline No & 80 & 35 & 45 & \\
\hline Yes & 20 & 7 & 13 & \\
\hline
\end{tabular}

MG, myasthenia gravis; SD, standard deviation.

Table III. Slug expression in normal thymus tissues and thymoma tissues.

\begin{tabular}{|c|c|c|c|c|}
\hline \multirow[b]{2}{*}{ Tissues } & \multicolumn{2}{|c|}{ Slug } & \multirow[b]{2}{*}{ Total, $\mathrm{n}$} & \multirow[b]{2}{*}{ P-value } \\
\hline & $\begin{array}{c}\text { Positive, } \\
\text { n }(\%)\end{array}$ & $\begin{array}{c}\text { Negative, } \\
\mathrm{n}(\%)\end{array}$ & & \\
\hline Normal thymus & $9(15.0)$ & $51(85.0)$ & 60 & $<0.001$ \\
\hline Thymoma & $51(51.0)$ & $49(49.0)$ & 100 & \\
\hline
\end{tabular}

group. The overall survival rates were determined using the Kaplan-Meier method, and group differences were calculated using the log-rank test. Prognostic factors were examined by univariate analysis using the Kaplan-Meier method and by multivariate analysis using the Cox proportional hazards regression model. P-values were two-sided, and $\mathrm{P}<0.05$ was considered to indicate a statistically significant difference. All statistical analyses were performed using SPSS software, version 18.0 (SPSS Inc., Chicago, IL, USA).

\section{Results}

Expression of Slug in normal thymus and in thymoma tissues. Slug was expressed in the cytoplasm of normal thymus tissues in $9 / 60$ specimens (15.0\%; Fig. 1, tissues N1 and N2), and Slug was expressed in the cytoplasm or nucleus of thymoma tissues in 51/100 specimens $(51.0 \%$; Fig. 1, tissues classified as A, AB, B1, B2, B3 and C). Notably, cytoplasmic Slug expression was 

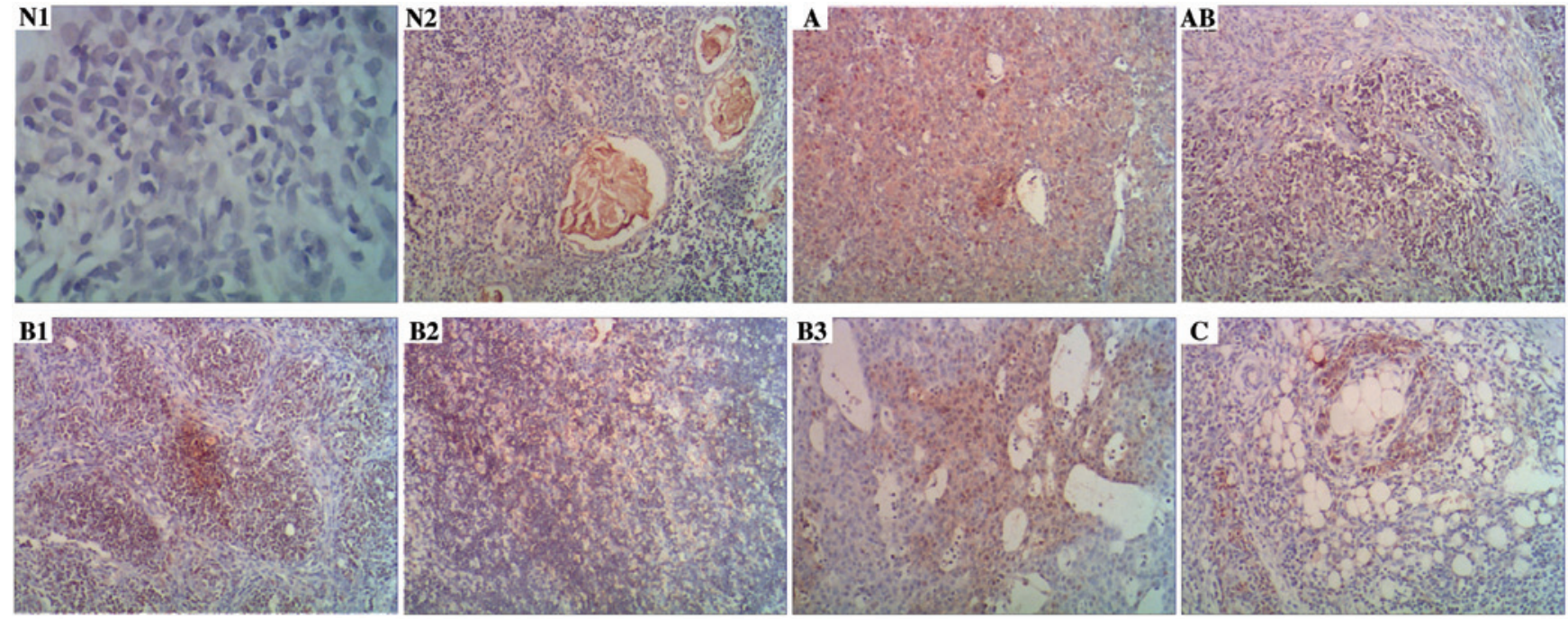

Figure 1. Expression of Slug in thymoma. Representative examples of negative expression (N1; magnification, x200) and positive expression (N2; magnification, x200) of Slug in normal thymus tissues are shown. In addition, representative examples of positive Slug expression in type A, AB, B1, B2, B3 and C thymomas are shown (magnification, $\mathrm{x} 200$ ).

Table IV. Univariate analyses of prognostic factors in thymoma.

\begin{tabular}{lccr}
\hline Variables & Total, $\mathrm{n}$ & $\begin{array}{c}\text { 10-year survival } \\
\text { rate, } \%\end{array}$ & P-value \\
\hline Gender & & & 0.642 \\
Male & 54 & 75.9 & \\
Female & 46 & 69.6 & $<0.001$ \\
Group & & & \\
Positive & 51 & 56.9 & $<0.001$ \\
Negative & 49 & 89.8 & \\
Stage & & & $<0.001$ \\
I and II & 67 & 89.6 & \\
III and IV & 33 & 39.4 & 0.812 \\
Classification & & & \\
A, AB, B1 & 55 & 94.5 & \\
B2, B3, C & 45 & 46.7 & \\
MG & & 75.0 & \\
No & 80 & 72.5 & \\
Yes & 20 & & \\
\hline
\end{tabular}

MG, myasthenia gravis

Table V. Multivariate analyses of prognostic factors in thymoma patients.

\begin{tabular}{lccc}
\hline Independent factors & P-value & HR & $95 \%$ CI \\
\hline Stage (I, II/III, IV) & 0.026 & 0.328 & $0.123-0.872$ \\
Classification (A, AB, & 0.003 & 0.143 & $0.040-0.507$ \\
B1/B2, B3, C) & & & \\
Group (positive/negative) & 0.089 & 0.401 & $0.139-1.151$
\end{tabular}

HR, hazard ratio; CI, confidence interval.

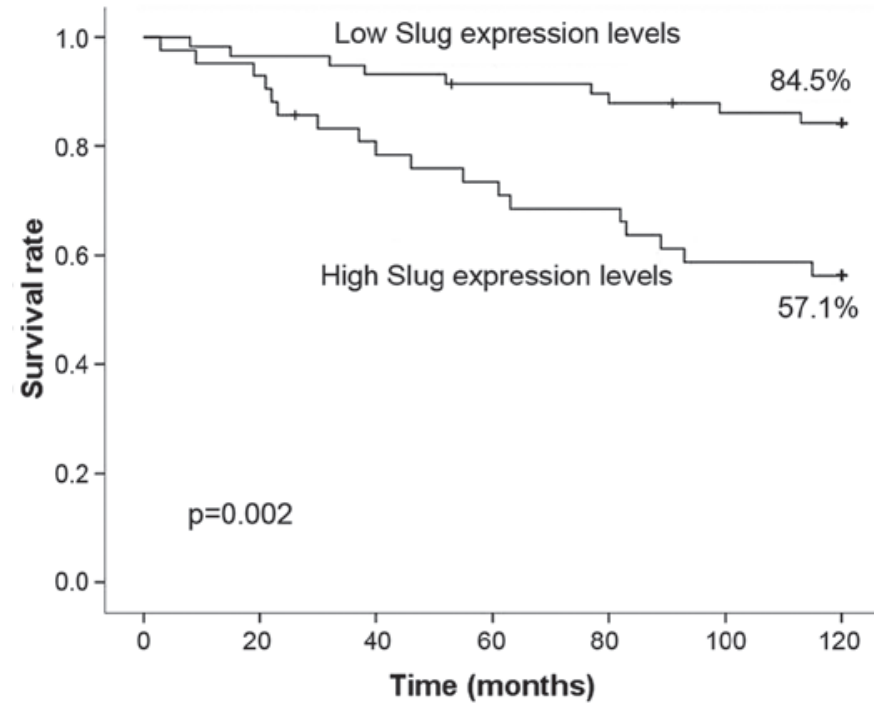

Figure 2. The 10-year survival curves of thymoma patients according to the Slug expression levels (low or high). A statistically significant difference was identified between the high-level and low-level Slug expression groups $(\mathrm{P}=0.002)$.

significantly increased in thymoma tissues compared to that observed in normal thymus tissues $(\mathrm{P}<0.001$; Table III).

Slug expression and clinicopathological characteristics. To evaluate the association between clinicopathological factors and Slug expression in thymoma, the specimens were divided based on staining scores into the low-level (score $\leq 3$, including negative expression) and high-level groups (score $>3$; Table II). The Masaoka stages and WHO classifications of the high-level group were significantly different compared with those of the low-level group. Patients with advanced stage thymoma exhibited increased levels of Slug expression compared with patients with early-stage thymoma $(\mathrm{P}<0.001)$. Furthermore, type B2, B3 and C thymomas exhibited increased levels of Slug expression compared with type A, AB 
and $\mathrm{B} 1$ thymomas $(\mathrm{P}=0.013)$. Slug expression did not correlate with age, gender or myasthenia gravis (all $\mathrm{P}>0.05$ ).

Association between prognosis and Slug expression. The follow-up time was $>120$ months, during which 1 patient succumbed to a heart attack and another 2 patients did not complete the follow-up. Patients in the low-level group exhibited a significantly increased 5-year survival rate of 91.4\% (53/58) compared with $73.8 \%$ (31/42) for patients in the high-level group ( $\mathrm{P}=0.016$; Fig. 2). Patients with low Slug expression levels also exhibited a significantly increased 10-year survival rate of $84.5 \%$ (49/58) compared with a rate of $57.1 \%$ (24/42) for patients with high Slug expression levels ( $\mathrm{P}=0.002$; Fig. 2).

Univariate and multivariate analyses of prognostic factors. Univariate analysis demonstrated that overexpression of Slug, the Masaoka stage and WHO classification of the tumor were significantly correlated with patient survival $(\mathrm{P}<0.05$; Table IV). Multivariate analysis using the Cox proportional hazards regression model indicated that the Masaoka stage and WHO classification, but not Slug expression, were independent prognostic factors in patients with thymoma (Table V).

\section{Discussion}

At present, thymoma is regarded as a potentially malignant tumor with a growth pattern that ranges from indolent to highly invasive and metastatic (4). Disruption of cellular activities that are important for normal embryonic development and for the maintenance of proper function and structure results in the loss of tissue differentiation and facilitates invasion and metastasis (10). Therefore, certain epithelial markers and adhesion molecules, including E-cadherin and Slug, are important for tumor progression and development (17).

Epithelial-mesenchymal transition (EMT), a process through which epithelial cells lose their polarity and switch to a migratory sarcomatoid phenotype, is a critical event during malignant tumor progression and metastasis (18). A hallmark of EMT is the loss of expression of the cell adhesion molecule E-cadherin, and several EMT regulators have been identified as E-cadherin repressors (19). Slug is a member of the Snail family of transcription factors and is crucial in the regulation of EMT by suppressing E-cadherin, therefore triggering complete EMT and the acquisition of invasive and tumorigenic properties $(10,20)$. The aim of the present study was to investigate the Slug expression patterns in thymomas in addition to the association between Slug expression levels and prognosis.

A previous study indicated that Slug is expressed in the thymus, heart, liver, lung and pancreas in humans (21). Using immunohistochemistry, the present study demonstrated that $15 \%$ of normal thymus tissues expressed Slug at low levels. Previous studies demonstrated that Slug expression correlates with prognosis in patients with esophageal squamous cell carcinoma, gastric cancer and colorectal carcinoma $(10,11,22)$. To the best of our knowledge, this is the first study on the expression and clinical significance of Slug in thymoma.

Slug has an anti-apoptotic effect in leukemia cells $(23,24)$, and downregulates epithelial markers, including Muc-1, desmoplakin and cytokeratin-18 $(25,26)$. The downregulation of certain anti-apoptotic cadherins is associated with poor prognosis in patients. E-cadherin is a major cell-cell adhesion molecule that is critical for the development and maintenance of cell polarity and tissue architecture $(27,28)$. Although E-cadherin expression was not analyzed in the present study, previous studies have reported that Slug represses E-cadherin in vivo and that E-cadherin expression is associated with poor prognosis in esophageal squamous cell and breast carcinomas $(11,12)$.

The most common disease associated with thymoma is myasthenia gravis, which is an autoimmune neuromuscular disease caused by antibodies that block acetylcholine receptors in muscle, resulting in muscle weakness $(29,30)$. A previous study revealed that the anti- $\mathrm{K}_{\mathrm{V}} 1.4$ antibody was a predictor of prognosis in patients with thymoma-associated myasthenia gravis (31). However, in the current study, the expression of Slug was not associated with myasthenia gravis.

While Slug expression was significantly associated with patient survival in the univariate analysis, it was not an independent prognostic factor in the multivariate analysis. However, the overall survival rate of thymoma patients with high levels of Slug expression was lower compared with thymoma patients with low levels of Slug expression.

There are certain limitations in the present study, including the long observation period (leading to the loss of patients to follow-up) and the relatively small number of patients. Thus, these findings should be tested and validated in a larger scale study that includes more patients.

In conclusion, Slug expression was found to be associated with prognosis, Masaoka stage and WHO classification, while overexpression of Slug correlated with poor prognosis in patients with thymoma. Therefore, Slug may serve as a predictor of poor prognosis in patients with thymoma and as a diagnostic biomarker of thymoma. In addition, Slug may be a potential target for the treatment of thymoma.

\section{References}

1. Chen G, Marx A, Chen WH, Yong J, Puppe B, Stroebel P and Mueller-Hermelink HK: New WHO histologic classification predicts prognosis of thymic epithelial tumors: A clinicopathologic study of 200 thymoma cases from China. Cancer 95: 420-429, 2002

2. Venuta F, Anile M, Diso D, Vitolo D, Rendina EA, De Giacomo T, Francioni $\mathrm{F}$ and Coloni GF: Thymoma and thymic carcinoma. Eur J Cardiothorac Surg 37: 13-25, 2010.

3. Wright CD: Management of thymomas. Crit Rev Oncol Hematol 65: 109-120, 2008

4. Evoli A,Minisci C,Di Schino C, Marsili F, Punzix C, Batocchi AP, Tonali PA, Doglietto GB, Granone P, Trodella L, et al: Thymoma in patients with MG: Characteristics and long-term outcome. Neurology 59: 1844-1850, 2002.

5. Nieto MA, Sargent MG, Wilkinson DG and Cooke J: Control of cell behavior during vertebrate development by Slug, a zinc finger gene. Science 264: 835-839, 1994.

6. Peinado H, Portillo F and Cano A: Transcriptional regulation of cadherins during development and carcinogenesis. Int J Dev Biol 48: 365-375, 2004.

7. Yang HW, Menon LG, Black PM, Carroll RS and Johnson MD: SNAI2/Slug promotes growth and invasion in human gliomas. BMC Cancer 10: 301, 2010.

8. Vesuna F, van Diest P, Chen JH and Raman V: Twist is a transcriptional repressor of E-cadherin gene expression in breast cancer. Biochem Biophys Res Commun 367: 235-241, 2008.

9. Nieto MA: The snail superfamily of zinc-finger transcription factors. Nat Rev Mol Cell Biol 3: 155-166, 2002.

10. Shioiri M, Shida T, Koda K, et al: Slug expression is an independent prognostic parameter for poor survival in colorectal carcinoma patients. Br J Cancer 94: 1816-1822, 2006. 
11. Uchikado Y, Natsugoe S, Okumura H, Setoyama T, Matsumoto M, Ishigami S and Aikou T: Slug Expression in the E-cadherin preserved tumors is related to prognosis in patients with esophageal squamous cell carcinoma. Clin Cancer Res 11: 1174-1180, 2005.

12. Hajra KM, Chen DY and Fearon ER: The SLUG zinc-finger protein represses E-cadherin in breast cancer. Cancer Res 62: 1613-1618, 2002.

13. Hasan MR, Sharma R, Saraya A, Chattopadhyay $\approx$ TK DattaGupta S, Walfish PG, Chauhan SS and Ralhan R: Slug is a predictor of poor prognosis in esophageal squamous cell carcinoma patients. PLoS One 8: e82846, 2013.

14. Travis WD, Brambilla E, Müller-Hermelin HK and Harris CC (eds): Pathology and Genetics. Tumours of the lung, pleura, thymus and heart. In: World Health Organisation Classification of Tumors. IARC Press, Lyon, 142-143, 2004.

15. Masaoka A, Monden Y, Nakahara K and Tanioka T: Follow-up study of thymomas with special reference to their clinical stages. Cancer 48: 2485-2492, 1981.

16. Sugimachi K, Aishima S, Taguchi K, et al: The role of overexpression and gene amplification of cyclin D1 in intrahepatic cholangiocarcinoma. J Hepatol 35: 74-79, 2001.

17. Barker $\mathrm{N}$ and Clevers $\mathrm{H}$ : Tumor environment: A potent driving force in colorectal cancer? Trends Mol Med 7: 535-537, 2001.

18. Grünert S, Jechlinger $M$ and Beug H: Diverse cellular and molecular mechanisms contribute to epithelial plasticity and metastasis. Nat Rev Mol Cell Biol 4: 657-665, 2003.

19. Thiery JP and Sleeman JP: Complex networks orchestrate epithelial-mesenchymal transitions. Nat Rev Mol Cell Biol 7: $131-142,2006$

20. Alves CC, Carneiro F, Hoefler H and Becker KF: Role of the epithelial-mesenchymal transition regulator Slug in primary human cancers. Front Biosci (Landmark Ed) 14: 3035-3050, 2009

21. Hemavathy K, Guru SC, Harris J, Chen JD and Ip YT: Human Slug is a repressor that localizes to sites of active transcription. Mol Cell Biol 20: 5087-5095, 2000

22. Uchikado Y, Okumura H, Ishigami S, et al: Increased Slug and decreased E-cadherin expression is related to poor prognosis in patients with gastric cancer. Gastric Cancer 14: 41-49, 2011.
23. Hemavathy K, Ashraf SI and Ip YT: Snail/slug family of repressors: Slowly going into the fast lane of development and cancer. Gene 257: 1-12, 2000

24. Inukai T, Inoue A, Kurosawa H, Goi K, Shinjyo T, Ozawa K, Mao M, Inaba T and Look AT: SLUG, a ces-1-related zinc finger transcription factor gene with antiapoptotic activity, is a downstream target of the E2A-HLF oncoprotein. Mol Cell 4: 343-352, 1999.

25. Cano A, Pérez-Moreno MA, Rodrigo I, Locascio A, Blanco MJ, del Barrio MG, Portillo F and Nieto MA: The transcription factor snail controls epithelial-mesenchymal transitions by repressing E-cadherin expression. Nat Cell Biol 2: 76-83, 2000.

26. Guaita S, Puig I, Franci C, Garrido M, Dominguez D, Batlle E, Sancho E, Dedhar S, De Herreros AG and Baulida J: Snail induction of epithelial to mesenchymal transition in tumor cells is accompanied by MUC1 repression and ZEB1 expression. J Biol Chem 277: 39209-39216, 2002.

27. Frixen UH, Behrens J, Sachs M, Eberle G, Voss B, Warda A Löchner D and Birchmeier W: E-cadherin-mediated cell-cell adhesion prevents invasiveness of human carcinoma cells. J Cell Biol 113: 173-185, 1991.

28. Hirohashi S: Inactivation of the E-cadherin-mediated cell adhesion system in human cancers. Am J Pathol 153: 333-339, 1998.

29. Grob D, Brunner N, Namba T and Pagala M: Lifetime course of myasthenia gravis. Muscle Nerve 37: 141-149, 2008.

30. Vincent A, Willcox N, Hill M, Curnow J, MacLennan C and Beeson D: Determinant spreading and immune responses to acetylcholine receptors in myasthenia gravis. Immunol Rev 164: 157-168, 1998.

31. Suzuki S, Nishimoto T, Kohno M, Utsugisawa K, Nagane Y, Kuwana M and Suzuki N: Clinical and immunological predictors of prognosis for Japanese patients with thymoma-associated myasthenia gravis. J Neuroimmunol 258: 61-66, 2013. 